\title{
Characterizing rainfall-runoff signatures from microcatchments with contrasting land cover characteristics in southern Amazonia
}

Article

Accepted Version

Guzha, A. C., Nobrega, R. L. B., Kovacs, K., RebolaLichtenberg, J., Amorim, R. S. S. and Gerold, G. (2015) Characterizing rainfall-runoff signatures from microcatchments with contrasting land cover characteristics in southern Amazonia. Hydrological Processes, 29 (4). pp. 508-521. ISSN 0885-6087 doi: https://doi.org/10.1002/hyp.10161 Available at https://centaur.reading.ac.uk/76899/

It is advisable to refer to the publisher's version if you intend to cite from the work. See Guidance on citing.

Published version at: https://onlinelibrary. wiley.com/doi/abs/10.1002/hyp.10161

To link to this article DOI: http://dx.doi.org/10.1002/hyp.10161

Publisher: Wiley InterScience

All outputs in CentAUR are protected by Intellectual Property Rights law, including copyright law. Copyright and IPR is retained by the creators or other copyright holders. Terms and conditions for use of this material are defined in the End User Agreement. 


\section{www.reading.ac.uk/centaur}

\section{CentAUR}

Central Archive at the University of Reading

Reading's research outputs online 


\title{
Characterizing rainfall runoff signatures from micro catchments with contrasting land cover characteristics in southern Amazonia
}

\author{
A.C. Guzha ${ }^{1}$, R. Nobrega ${ }^{1}$, K. Kovacs ${ }^{1}$, J. Rebola-Lichtenberg ${ }^{2}$, R.S. Amorim ${ }^{3}$, and G. Gerold ${ }^{1}$
}

1. Department of Geography and Geosciences, Georg-August University, Gottingen, GERMANY

2. Faculty of Forest Sciences \&Forest Ecology, Georg-August University, Gottingen, GERMANY

3. Faculdade de Agronomia e Medicina Veterinária, UFMT,Boa Esperança, Cuiabá, BRAZIL alphonce-c.guzha@geo.uni-goettingen.de

\begin{abstract}
Based on interactions between landscape characteristics and precipitation inputs, watersheds respond differently to different climatic inputs. The objective of this study was to quantitatively characterize controls on runoff generation from two first order micro-catchments in the Amazonia region. The study investigated the variation of hydrological signatures at micro-catchment scale, and relates these to landscape and land cover differences and weather descriptors that control the observed responses. One catchment is a pasture cleared of all natural vegetation in the early 1980's and the second catchment is a primary tropical forest with minor signs of disturbance. Water levels and meteorological variables were continuously monitored during the study period (December 2012-May 2013). Water level measurements were converted to discharge, evapotranspiration was quantified using Penman-Monteith equation and catchment pedohydrological properties were also determined. During the study period, mean total rainfall was $1200 \mathrm{~mm}$ and runoff ratios were 0.79 and 0.47 for the pasture and forest catchments, respectively. Base flow index was relatively higher in the forest catchment (0.76) compared to pasture catchment (0.63). Results from this study showed that the pasture catchment had a 35\% higher mean stream flow. Analysis of selected individual rainstorm events also showed peak discharges were attained much faster in the pasture catchment compared to the forest catchment. At both sites, rainfall-runoff responses were highly dependent on surface and subsurface flow generation. Overland flow was observed in the pasture site during intense rainfall events. The pasture catchment exhibited higher event water contribution than the forest catchment. Findings from this research suggest that shallow lateral pathways play a significant role in controlling runoff generation processes in the forest catchment, while infiltration excess runoff generation processes dominate in the pasture catchment. Results from this study suggest that the conversion of forest to pasture may lead to important changes in runoff generation processes and water storage in these head water catchments.
\end{abstract}

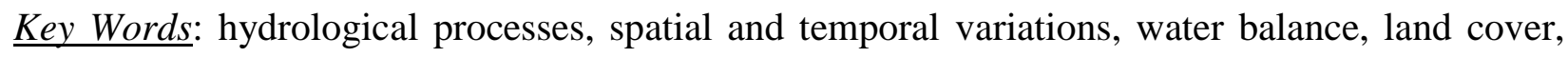
Amazonia. 
Even though there is a general agreement on the importance of the Amazonia forest to world's climate, rainfall patterns and water resources, there is relatively limited research on examining the influences of land use changes on catchment hydrology in the humid tropics (Roa-Garcia and Weiler, 2010; Roa-Garcia et al., 2011). Tropical forest watersheds are valuable terrestrial ecosystems for biodiversity and provision of water related ecosystem services (Hamilton et al., 1995; Tognetti et al., 2010; Zadroga, 1981). However, dramatic degradation in these ecosystems have occurred in the last few decades (Scatena et al., 2010). While there is substantial evidence that the conversion of forest to pasture or crops in the tropics is associated with an increase in annual stream flow totals because of the lower evapotranspiration of the replacement vegetation, there have been reports of diminished stream flows during the dry season, and in this respect, the effects of tropical forest conversion on catchment hydrology are even less understood (Bruijnzeel et al., 2011). Scientific conclusions and inferences generated from modeling efforts have often been tampered with limited field data and based on model parameter calibration and thus increased uncertainty in the model predictions. As stated by Blume et al. (2007), basin inter-comparison and maximization of the scientific value of available data sets, and field campaigns are important in order to generate data sets for catchments and watersheds in various study regions.

Headwater catchments can be play a significant role in understanding the influence of anthropogenic and climate changes on stream flow dynamics because of their relatively small contributing areas which make them highly responsive to changes in energy, water, and chemical inputs (Roa-García et al., 2011). The low-order streams in these catchments are the sources or origins for larger rivers and therefore may serve as useful indicators for different catchment stresses.

Classical and recent studies show that hydrologic properties of catchments, including infiltration and hydraulic conductivity are strongly affected by various stresses (Alegre and Cassel, 
1996; Schoenholtz et al., 2000) and these properties play a key role in surface and sub-surface flow paths, and runoff generation (Elsenbeer, 2001; Elsenbeer and Lack, 1996) and subsequently hydrochemical dynamics. While the intensity and amount of rainfall is a key factor, recent studies give rise to the assumption that other factors than the amount of precipitation play an important role in controlling seasonal patterns of catchment hydrochemical signatures (Breitenbach et al., 2010; Feng et al., 2009; Kebede and Travi, 2011; Lee et al., 2009).

Schnorbus and Alila (2013) observed that land use change did not have a statistically significant $(\alpha=0.05)$ impact on the peak flow distribution until a threshold level (20-30\%) in spatial extent of the land use change (forest harvesting in their case). They also noted that the magnitude of peak flow change is a function of changes in input fluxes (rainfall minus evapotranspiration) and changes in runoff synchronization, which directly affect peak discharge magnitude and timing. Thus understanding catchment characteristics is an important prerequisite to evaluating effects of various (anthropogenic and climatic drivers) in catchment hydrological responses, and subsequent hydro chemical dynamics.

As outlined by Pfeffer et al. (2013), existing data and knowledge points out the central role of land use and confirm that land cover changes have a greater impact on runoff production than the rainfall deficit [Séguis et al., 2004; Boulain et al.,2009; Massuel et al., 2011]. However, as highlighted by Cappelaere et al., (2009), finer process understanding is needed to understand and explain the observed surface fluxes and improve future water management scenarios.

Results presented in this paper are part of a project which aims to develop a decision support tool to alleviate land use intensification associated problems such as losses of ecosystem services like the loss of natural vegetation and associated ecosystem functions in the global and regional climate system, increasing emissions of greenhouse gases (GHG), and the reduction of livelihoods. This paper examines the rainfall runoff relationships and the various controls of 
catchment hydrology in micro-catchments in which a further source of variability in the study catchments is the contrasting land use. We focused our study in a natural forest catchment and a pasture catchment in which the original forest trees have been removed and replaced with Brachiaria brisanta grass for intensive cattle rearing. To reduce the effect of spatial variability, typical for the medium-sized and large basins, this study focuses on micro-catchments less than 1 $\mathrm{km}^{2}$ in spatial extent. The objective of the study was to understand how stream flow is conditioned by microclimate, precipitation pattern, land cover and soil properties, amongst other catchment properties. We examine the catchment physiographic characteristic in relation to observed stream flow dynamics for selected rain storms and also how these are likely related to current land use and land cover patterns. This paper is a contribution to the understanding of process hydrology by characterizing the hydrological behavior of small headwater catchments in active deforestation zones of Southern Para State on the south east of the Amazonia.

Our central hypothesis is that clearing for pastures and agricultural development leads to increased flashiness of catchment discharge dynamics and also reduces dry season flows. By quantifying the water balance components of the selected catchments we test the infiltration tradeoff hypothesis for tropical environments and the applicability of the linear reservoir concept. The following sections provide a description of the studied catchment; details of the chosen methodologies for the analysis; and an overview of results.

\section{Location}

\section{STUDY SITE AND METHODS}


The experimental catchments are located within the boundaries of Fazenda Paraiso $\left(7.042^{\circ} \mathrm{S}, 55.385^{\circ} \mathrm{W}\right)$, which is about $5 \mathrm{~km}$ from the town of Novo Progresso in Southern Para Brazil (Figure1) and situated in the watershed of the Jamanxim River, one of the major southern subtributaries of the Amazon River. The climate at the study area is humid tropical with a rainy season from November to April and a dry season that extends from May to October. Mean annual precipitation averages $1900 \mathrm{~mm}$. Figure 2 shows typical soil profiles in the study area, and tables 1 and 2 show the basic soil profile horizon characteristics for the two study catchments. The dominant soils are Lixisols (Haplustox / Latossolo vermelho-amarelo distrófico (Brazil classification)) with sandy clay texture (mean soil texture of $55 \%$ sand, $2 \%$ silt, and $43 \%$ clay) (Soil Survey Staff, 1999). Lixisols are related to the Oxisol order of the U.S. Soil Taxonomy. The pasture catchment with an area of 30 ha is covered by pasture grass (Brachiaria brisanta). The forest catchment with an area of 55 ha is located approximately $1.5 \mathrm{~km}$ from the pasture catchment, on the south eastern fringe of the farm is generally a natural forest with existing signs of vegetation/tree regrowth and the existence of tree logging sites.

\section{Methods}

\section{Rainfall and weather data}

In order to capture the rainfall variability within the catchments, a network of tipping bucket rain gages was installed. In the pasture catchment, four tipping buckets with data loggers (Tinytag, Gemini, UK) were installed. Three tipping buckets were at the forest catchment. Each of the tipping buckets has a resolution of $0.2 \mathrm{~mm}$ and rainfall was recorded at 10 minutes intervals. A weather station was installed within the pasture catchment with sensors to measure total solar radiation, net solar radiation, temperature, relative humidity, wind speed and direction and rainfall. Data was logged on a 10 minute time interval using GP1 loggers. From this data, reference 
evapotranspiration was quantified using the Penman-Monteith equation following the procedure presented by Allen et al. (1998).

$$
\mathrm{ET}_{\mathrm{o}}=\frac{0.408 \Delta\left(\mathrm{R}_{\mathrm{n}}-\mathrm{G}\right)+\gamma \frac{900}{\mathrm{~T}+273} \mathrm{u}_{2}\left(\mathrm{e}_{\mathrm{s}}-\mathrm{e}_{\mathrm{a}}\right)}{\Delta+\gamma\left(1+0.34 \mathrm{u}_{2}\right)}
$$

where:

ETo reference evapotranspiration [mm/day], Rn surface net radiation $\left[\mathrm{MJ} / \mathrm{m}^{2} /\right.$ day], G soil heat flux density $\left[\mathrm{MJ} \mathrm{m}^{-2}\right.$ day $\left.^{-1}\right]$, T mean daily air temperature at $2 \mathrm{~m}$ height $\left[{ }^{\circ} \mathrm{C}\right]$, $\mathrm{u}_{2}$ wind speed at $2 \mathrm{~m}$ height $\left[\mathrm{m} \mathrm{s}^{-1}\right], \mathrm{e}_{\mathrm{s}}$ saturation vapor pressure $[\mathrm{kPa}], \mathrm{e}_{\mathrm{a}}$ actual vapor pressure $[\mathrm{kPa}], \mathrm{e}_{\mathrm{s}}-\mathrm{e}_{\mathrm{a}}$ saturation vapor pressure deficit $[\mathrm{kPa}], \Delta$ slope vapor pressure curve $\left[\mathrm{kPa}{ }^{\circ} \mathrm{C}^{-1}\right], \gamma$ psychrometric constant $\left[\mathrm{kPa}^{\circ} \mathrm{C}^{-}\right.$ $\left.{ }^{1}\right]$. The grassland vegetation in the pasture catchments is perennial grasses with minimal seasonal growth stage variation and few scattered trees and shrubs. Therefore uniform Kc values were utilized to estimate actual evapotranspiration. Similarly, in the forest catchment a relatively uniform canopy of hardwood trees 20-30m tall cover the entire catchment all year through and therefore a uniform Kc value was used to quantify actual evapotranspiration.

\section{Catchment Discharge}

At the catchment outlets, rectangular weirs were built and each weir was fitted with a DS 5X multiparameter sonde (OTT) which measured water level, electrical conductivity, $\mathrm{pH}$, turbidity, dissolved oxygen (LDO) and temperature at 15-minute intervals. The standard rectangular weir equation based on the Bernoulli equation was used to estimate the catchment discharge (flow rate).

$Q=\frac{2}{3} C_{d} b(\sqrt{2 g}) h^{\frac{3}{2}}$

where

Q: discharge over weir ( $\left.\mathrm{m}^{3} / \mathrm{s}\right)$; Cd: discharge coefficient; b: weir length (m); h: head on weir (m)

In order to understand the temporal dynamics in the hydrological response of the study catchments we examined the rainfall-run off relationships exhibited in the obtained discharge data for the time 
period from January 2013 to the end of May 2013. This coincides with the rainy season in the study area. A few rainy storms were missed in November and December due to delays in field equipment installation.

\section{Soil Moisture}

From a hydrologic viewpoint, soil moisture controls the partitioning of rainfall into runoff and infiltration and therefore has an important effect on the runoff behavior of catchments (Aubert et al., 2003). Time domain reflectometry (TDR) was used to monitor soil moisture dynamics. The TDR system was used to measure volumetric water content on a weekly basis, with TECANAT access tubes installed to a depth of $200 \mathrm{~cm}$ in two transects in each catchment. The study catchments feature a toposequence of landscape positions from a gently sloping upper plateau, a middle slope and a low-gradient valley bottom. Access tubes were installed along this toposequence and thus the measured soil moisture represents water content dynamics along this toposequence. We used a TRIME-PICO T3 probe (IMKO Micromodultechnik GmbH, Ettlingen, Germany) to take measurements of volumetric water content at the following soil depth intervals: 0-20, 20-40, 40-60, 60-80, 80-100, 100-120, 120-140, 140-160 and 180-200 cm. Since the TRIME probe measures water content in an elliptical field, two measurements were taken at each depth increment and averaged to account for local and spatial variability in water content.

Detailed hydraulic properties (saturated hydraulic conductivity and bulk density) characterizing these catchments was also quantified. A constant head permeameter (Amoozemeter) designed by Amoozegar (1989a) for in situ measurements above the water table was used to estimate hydraulic conductivity. This was done by augering a borehole at $25 \mathrm{~cm}$ depth and at 40 cm depth, establishing a constant water head in the hole and calculating Ks from the steady-state infiltration rate using the Glover equation (Amoozegar, 1989b). We measured Ksat at 25 and 40 $\mathrm{cm}$. Particle size distribution of the soils was measured using the pipette method (Gee and Bauder, 
1986) after chemical dispersion and removal of organic matter and carbonate contents. Soil bulk density was estimated using undisturbed samples dried in an oven at $105{ }^{\circ} \mathrm{C}$ (Burke et al., 1986). Soil particle density was measured in the laboratory using the pycnometer method of Blake and Hartge (1986) and total porosity was determined from bulk density and particle density values.

\section{Hydrograph separation}

In line with procedures utilized by Recha et al. (2012), for the study period, the stream hydrographs were normalized using the approximate catchment area in order to allow a comparison of the catchments. Using discharge data, the Runoff Ratio (RR) was quantified as the ratio of total runoff to total rainfall. The discharge data were further analyzed using hydrograph separation techniques implemented in the Web GIS-based Hydrograph Analysis Tool (WHAT) using the recursive digital filter method for base flow separation (Lim et al. 2005; Lim et al. 2010). From this analysis, we obtained base flow and storm flow components of the runoff ratio (RRBF and RRSF as the ratio of total base flow and storm flow to total rainfall, respectively). The base flow index (BFI) is the ratio of base flow to total discharge (Bloomfield et al. 2009). Flow duration curves were calculated to compare the differences in high, low, and median flows across the catchments (Vogel and Fennessey 1994). The Baker et al (2004) method was used to estimate catchment flashiness indices.

Using the monitoring data, a water balance for each study catchment can be constructed as follows:

$$
\mathrm{P}=\mathrm{R}+\mathrm{ET}+\Delta \mathrm{S}
$$


where $\mathrm{P}$ the rainfall, $\mathrm{R}$ is the surface water flow out of the catchment, ET is the evapotranspiration, and $\Delta \mathrm{S}$ is the water content change in the unsaturated zone and recharge to saturated zone. $\Delta \mathrm{S}$, thus, includes lateral as well as vertical groundwater losses and gains from the catchment as well as error in estimating all mass balance components on the right hand side of Equation 3. Due to logistical difficulties and equipment shortages we could not quantify aquifer recharge and therefore in the water balance this term is lumped together with unsaturated zone water content.

\section{RESULTS AND DISCUSSION}

In this section, the results obtained from the two study catchments are presented. We analyze the rainfall characteristics, pattern and variability between these two sites and the major soil profile characteristics. After this, we present and discuss measured soil moisture dynamics

over the study period, stream discharge characteristics and quantified actual evapotranspiration variations in the study catchments.

\section{Precipitation characteristics}

Figure 3 shows the daily rainfall amounts in each catchment. During the study period (December 2012 to May 2013) the pasture catchment received $1254 \mathrm{~mm}$ of rainfall while $1190 \mathrm{~mm}$ was recorded in the forest catchment. Given the convective rainfall typical of the tropical regions we investigated spatial variability in daily rainfall amounts by comparing average daily accumulations recorded in the pasture site with those recorded by tipping buckets in the forest site. A scatter plot of the two sampling locations is shown in Figure 4. This figure shows high coefficient of determination $\left(\mathrm{r}^{2}=0.84\right)$ between these two sites. Considering the small size of the study catchments this analysis can provide confidence of using rainfall from only one site and apply to the other site. Rain events occur simultaneously at both locations. Most of the rainstorms are midafternoon storms of varying durations and peak intensities of $20 \mathrm{~mm} / 10 \mathrm{~min}$ and $23 \mathrm{~mm} / 10 \mathrm{~min}$ were 
observed in the pasture and forest catchments, respectively. Data analysis also shows the typical short, intense nature of tropical storms with mean storm duration of about 2 hours.

\section{Soil Profile Characteristics}

The forest catchment had a markedly lower mean bulk density $\left(1.2 \mathrm{~g} \mathrm{~cm}^{-3}\right)$ than the pasture catchment $\left(1.42 \mathrm{~g} \mathrm{~cm}^{-3}\right)$. This difference may be attributed to the higher root penetration and lack of compaction by the cattle in the forest catchment. The forest catchment exhibited a blocky structure while the pasture catchment had mainly blocky and platy structure. The platy structure in the pasture originates from compaction as a consequence of the operations for deforestation or cattle trampling.

Results from this study show that the saturated hydraulic conductivity was relatively lower in the pasture catchment compared to the forest catchment. The low Ksat values in the pasture catchment can be an indication of the absence of a well-defined macro pore structure. The forest catchment had more than six times higher rate of saturated hydraulic conductivity than the pasture. That means moderately rapid infiltration and subsequently lower probability of runoff. Most probably the higher organic matter content and the lower bulk density in the forest favor the infiltration of water. Even though our study was only limited to two depths of measurements $(25 \mathrm{~cm}$ and $40 \mathrm{~cm})$, these results show relative anisotropy in Ksat with depth. Strong anisotropy has also been reported on oxisols in south western Amazonia (Elsenbeer et al., 1999).

\section{Soil Moisture variation}

From weekly soil moisture measurement data the average soil moisture content remained in the $15-35 \%$ range during most of the measurement period. While soil moisture measurements were done on a weekly basis, the lack of large peaks in soil moisture contents at both sites even one day after large rainfall events may suggest that there is rapid drainage in the soil profiles at 
these two sites. Drying out was also observed beginning at the top and decreasing with depth. As shown in Figure 5, generally soil moisture content variability between the two catchments was limited. The pasture catchment exhibited lower hydraulic conductivity, compared to the forest catchment. Therefore any greater surface inputs (rainfall) in the pasture catchment compared to the forest are likely offset by this difference in hydraulic conductivity. There is a general similarity in mean soil moisture contents between these two catchments. Maybe the drainage processes in these catchments behaves in similar ways and the soil profiles drain rapidly returning them to a standard level of water storage, maybe close to field capacity. This was observed by Hodnett et. al (1995) in central Amazonia catchments. Surface compaction in the pasture catchment will also likely be a reason for a delay in replenishment of soil moistures stores.

In the forest site, the soil profile was generally shallower with bedrock and presence of hardpan horizon observed. These soils most probably have little water storage capacities and thus limited soil water reservoirs as shown by the low water contents and also the plinthic horizons promote subsurface flow generation. The high base flow values observed in the forest catchment also support this observation. The low water contents in the forest may also suggest the great influence of root water extraction in the forest site. This trend was also observed by Hodnett et al. (1995), who noted that the great variation in soil moisture content between pasture and forest catchments in the Amazon.

As expected, Figure 5 also shows a general increase in soil moisture from the upslope to the bottom slope. Because the soil moisture measurements were manually done on weekly basis and at times suitable for field work, the highest soil moisture contents measured in both sites is likely to be between the saturation point and field capacity. In the pasture catchment the average Volumetric Moisture Content (VMC) was about 21\% while in the forest catchment this was about $24 \%$. These low VMC are typical in these lixisols which behave like sands in terms of water 
movement at low tensions but hold water like clay at high tensions (Sanchez (1976) in Hodnett et al. (1995).

\section{Catchment Discharge}

Figure 6 shows the peak daily stream lows at the 2 sites and Figure 7 shows the normalized daily discharges. During the study period, mean and peak discharges were higher in the pasture catchment compared to the forest catchment. The mean discharge was $8 \mathrm{~mm} /$ day in the pasture catchment and $5 \mathrm{~mm} /$ day in the forest catchment and the peak discharge was $49 \mathrm{~mm} /$ day in the pasture catchment and $20 \mathrm{~mm} /$ day in the forest catchment. These results are similar to those obtained by Trancoso et al. (2007) in relatively similar catchments in the Amazon. These results show that land cover alterations impact on catchment water storage properties and this has direct effects on water quantity and water quality related ecosystem services.

The relative hydrological behavior of the study catchments in a wet season as shown through the FDCs (Figure 8) provides evidence of the major rainfall runoff control processes. The Flow Duration Curves indicated that the pasture catchment exhibits almost $50 \%$ high flows (0 to 5th percentiles on FDC) than the forest catchment. The pasture catchment discharges more water at all percentages of time that the discharge is equaled or exceeded. For example, a 10mm/day runoff is equaled or exceeded in the pasture catchment for $30 \%$ of the time while in the forest it is exceeded only for $10 \%$ of the time. Differences between the FDC's are limited during the low flow periods. To illustrate characteristics of individual flow events in the study catchments, two hydrographs were plotted for the rainfall storms of March 23 2013 (Figure 9). The runoff response was much faster in the pasture catchment with an average lag time of 25 minutes compared to 60 minutes for the forest catchment. In the forest catchment, the hydrograph shows a delayed response suggesting that sub surface flow and subsequent overland flow on saturated areas were important 
processes. As explained by Suryatmojo et al (2013), physical catchment parameters, such as slope, shape, main-stream slope and drainage density affect stream flow and influence the shape of the hydrograph through catchment storage, runoff speed, infiltration and soil water content. While the study catchments display similar patterns, when the flows begin to decline with the onset of the dry season, the flow of forest catchment decreases first.

Hydrologic indices calculated from discharge data for these two catchments are shown in Table 2. For almost similar rainfall totals during the study period, discharge normalized to catchment area was higher in the pasture catchment $(992 \mathrm{~mm})$ compared to the forest catchment (584 $\mathrm{mm})$. The average daily stream flow for the pasture catchment was $9.0 \mathrm{~mm}$ while it was 5.6 $\mathrm{mm}$ for the forest catchment. Runoff ratios were significantly higher in the pasture catchment $(0.79)$ than the forest catchment (0.46). However base flow contribution to stream flow was higher in the forest catchment (0.76) compared to the pasture (0.63).

For selected representative rainstorms in the study catchments, the hydrographs are shown in Figure 10 (a-c) for the two study catchments. For the rainstorm on February $26^{\text {th }} 2013,46 \mathrm{~mm}$ of rain produced $7 \mathrm{~mm}$ discharge at peak discharge rates of $0.24 \mathrm{~mm} / 10 \mathrm{~min}$ in the forest catchment while $55 \mathrm{~mm}$ of rain produced $31 \mathrm{~mm}$ of runoff at peak discharge rates of to $4 \mathrm{~mm} / 10 \mathrm{~min}$ in the pasture catchment. The runoff coefficient for the pasture site was almost five times higher than for the forest catchment. The March $18^{\text {th }}$ rainstorm $(120 \mathrm{~mm})$ produced $55 \mathrm{~mm}$ of runoff in the pasture catchment and on the same day $121 \mathrm{~mm}$ of rainfall produced only $26 \mathrm{~mm}$ runoff in the forest catchment. Similarly, on April $17^{\text {th }}, 39 \mathrm{~mm}$ of rain produced $23 \mathrm{~mm}$ runoff in the pasture while 38 $\mathrm{mm}$ of rain produced only $6 \mathrm{~mm}$ discharge in the forest catchment. These hydrologic signatures show the relationship between total precipitation, base flow and runoff, with land cover playing a significant role. As outlined by Bruijnzeel (2006), that even though it can be argued that a direct comparison of the catchments may lead to biased results because of inherent topographic 
differences between the two areas, it is pertinent to note that the relative size of the topographically controlled area potentially generating SOF was larger for the forest catchment than for the pasture. Thus, the larger peak flows observed for the pasture catchment cannot be attributed only to intrinsic differences in catchment topography. An increase of runoff in the pasture could mainly be attributed to an increase in infiltration excess (Hortonian) overland flow. As stated by Elsenbeer (2001) and Niedzialek and Ogden (2010), the observed runoff properties are typical of many tropical catchments with dominant source of water at the event scale being rapid lateral transport of water.

Most of the rainfall intensities in the pasture exceeded the Ksat values near the surface and this may mean that there are high frequencies of Hortonian overland flows occurring at this site. Moraes et al. (2006) observed similar results in pasture catchments in Eastern Amazonia. The higher discharges of the pasture catchment could be explained by the compaction of soil upper layers by cattle grazing in the grasslands relative to the characteristics of soils in forest catchment. Compaction reduces rainfall infiltration, reducing groundwater replenishment and promotes surface flows (Bruijnzeel, 2004). As observed by Roa-Garcia (2011), the high flows in the pasture catchment also indicates a smaller water storage capacity and higher surface runoff rates, related to grasslands that have less capacity to store water than forests. In the forest catchments, higher Ks values were observed and usually forest soils are dominant in vertical flow paths (Williams et at., 1997). However the occurrence of shallow impeding layers with the soil profiles in the forest result in significant increases in lateral flow contributing to stream flow. Overall results suggest that land use plays a significant role in any observed hydrologic signatures. The overall water balance for the study catchments during the study period (Table 4) shows that in the forest site, $49 \%$ of all rainfall inputs were discharged from the catchment while for the pasture catchment this amounted to $79 \%$. 
These catchment discharge results could provide important information on water storage, fluctuation and runoff in these tropical head water catchments and the ability of the ecosystems in the headwaters to regulate water flows. The transformation of the headwater catchments from forests and wetlands to grasslands and pastures is most likely contributing to the reduction in their water regulation capacity, as indicated by this research, and ultimately impacts on the potential of management to influence dry season flows and storm flow attenuation.

\section{Evapotranspiration}

Figure 11 shows time series of daily ET from each of the sites. The average ET in the forest catchment was $4.9 \mathrm{~mm} /$ day while in the pasture catchment the average daily ET was $3.6 \mathrm{~mm} /$ day. As asserted by Spracklen et al. (2012) that when forests are replaced by pasture or crops, evapotranspiration of moisture from soil and vegetation is often diminished, leading to reduced atmospheric humidity and potentially suppressing precipitation. Water budget calculation is a conceptual simple way to study the hydrological behavior of an ecosystem and provides a useful tool to assess the relative importance of the hydrological processes (Ingram, 1983; Price and Maloney, 1994). For the study catchments, water budget components for the study period are shown in Table 4. The quantification of ET using the semi empirical Penman-Monteith equation was based entirely on information provided by the meteorological station located in the pasture catchment. ET losses accounted for $35 \%$ of the water losses in the pasture site and $47 \%$ in the forest site. On the basis of these data, replacing forests with pastures and grasslands produces an increase in annual water yield. However, Roa-Garcia et al 2010, notes that rather than this effect as the main driver for the increase in annual flows after forest clearing, in the tropics it appears to be the reduced infiltration capacity of the soil.

\section{SUMMARY AND CONCLUSIONS}


We investigated the rainfall runoff characteristics of two small headwater catchments. Land cover and catchment physiographic parameters play a significant role in the hydrologic responses of the catchments. Data from this study highlight linkages between land cover and the rainfall runoff characteristics as shown in the discharge hydrographs. Analyses of individual events have shown relative differences between forest and pasture sites in terms of the rainfall-runoff responses. The pasture catchment exhibits high instantaneous peak discharges compared to the forest catchment. The pasture catchment exhibited relatively rapid response to precipitation compared to the forest catchment. Normalized discharge was also higher in the pasture catchment which also exhibited higher runoff ratios compared to the forest catchment. Initial findings confirm that hydrological responses in these catchments are driven by various factors and depend not only on the watershed features but also on prior conditions and the characteristics of the rainfall episodes, e.g. intensity. Both catchments are underlain by soils with well defined, A, E and Bt Horizons. Soil moisture exhibits temporal variations following rainfall patterns and spatially showing the influence of topography. During the study period there is limited variation in moisture reservoirs in the study catchments, and both catchments also exhibited limited ranges in available water capacities. Results of this study highlight that land cover alterations and transformation of the headwater catchments from forests most likely contributes to the reduction in their water regulation capacity. While results presented here provide a useful initial assessment of catchment hydrological controls, further research is ongoing to better understand the influence of land use and soil moisture on discharge over a longer time period and also to characterize the influence on hydrochemical transport. Further work will use these data to validate hydrological models identifying the actual pathways of the water in the catchments, calculate mean transit times, and quantify associated hydro-chemical fluxes. 


\section{ACKNOWLEDGEMENTS}

The authors wish to thank the Bundesministerin für Bildung und Forschung (BMBF) for supporting this research through their grant to the CARBIOCIAL project (Support Code: 01LL0902A) and the Deutscher Akademischer Austausch Dienst (DAAD) scholarship support for R. Nobrega. The authors also acknowledge the collaboration of field site host, Fazenda Missassi and thanks to Robert Müller and Alexander Kirst for field assistance.

\section{REFERENCES}

Alegre, J.C., Cassel, D.K. 1996. Dynamics of soil physical properties under alternative systems to slash-and-burn. Agric. Ecosyst. Environ. 58 (1), 39-48.

Allen, R.G.; Pereira, L.S.; Raes, D.; Smith, M. 1998. Crop evapotranspiration: guidelines for computing crop water requirements. Rome: FAO, 297p. FAO. Irrigation and Drainage Paper, 56 Amoozegar, A. 1989a. A compact, constant-head permeameter for measuring saturated hydraulic conductivity of the vadose zone. Soil Science Society Of America Journal. 53: 1356-1361. 
Amoozegar, A., 1989b. Comparison of the Glover solution with the simultaneous equations approach for measuring hydraulic conductivity. Soil Science Society of America Journal. 53: 1362-1367.

Aubert, D., Loumagne, C., and Oudin, L. 2003. Sequential assimilation of soil moisture and stream flow data in a conceptual rainfall runoff model, Journal of. Hydrology., 280:145-161.

Baker, D. B., P. Richards, T. T. Loftus, and J. W. Kramer .J.W. 2004. A new flashiness index: Characteristics and applications to Midwestern rivers and streams. Journal of American Water Resources. Association, 40: 503-522.

Blake, G. R. and Hartge, K. H. 1986. 'Bulk density', in Klute, A. (Ed.), Methods of Soil Analysis, Part I. Am. Soc. Agron., Madison, WI. pp. 363 -376.

Bloomfield, J. P., Allen, D.J. and Griffiths, K.J. 2009. Examining geological controls on baseflow index (BFI) using regression analysis: An illustration from the Thames Basin, UK. Journal of . Hydrology., 373: 164-176.

Blume T., Zehe, E and Bronstert A. 2007. Rainfall-runoff response, event-based runoff coefficients and hydrograph separation, Hydrological Sciences Journal, 52(5):843-862. http://dx.doi.org/10.1623/hysj.52.5.843.

Boulain, N., B., Cappelaere, L., Séguis, G., Favreau and Gignoux, J. 2009. Water balance and vegetation change in the Sahel: A case study at the watershed scale with an eco-hydrological model, Journal of Arid Environments., 73:1125-1135, DOI : 10.1016/j.jaridenv.2009.05.008

Breitenbach, S. F. M., Adkins, J. F., Meyer, H., Marwan, N., Kumar, K. K., and Haug, G. H. 2010. Strong influence of water vapor source dynamics on stable isotopes in precipitation observed in Southern Meghalaya, NE India, Earth Planet. Sc. Letters., 292:212-220, DOI:10.1016/j.epsl.2010.01.038.

Bruijnzeel, L.A. 2004. Hydrological functions of tropical forests: not seeing the soil for the trees?, 2004. Agriculture, Ecosystems and Environment 104: 185-228.

Bruijnzeel, L. A., Mulligan, M., and Scatena, F. N. 2011. Hydrometeorology of tropical montane cloud forests: emerging patterns, Hydrological Processes, 25, 465-498.

Bruijnzeel, L.A. 2006. Hydrological impacts of converting tropical montane cloud forest to pasture, with initial reference to northern Costa Rica. Final Technical Report DFID-FRP Project no. R7991. Vrije Universiteit, Amsterdam, and Forestry Research Programme of the U.K. Department for International Development, London, $52 \mathrm{pp}$. 
Burke, W., Gabriels, D., and Bouma, J. (Eds). 1986. Soil Structure Assessment. A. A. Balkema, Rotterdam. 93 pp.

Cappelaere, B., Descroix, L., Lebel, T., Boulain, N., Ramier, D., Laurent, J.-P., Favreau, G., Boubkraoui, S., Boucher, M., Moussa, I. B., Chaffard, V., Hiernaux, P., Issoufou, H. B. A., Le Breton, E., Mamadou, I., Nazoumou, Y., Oï, M., Ottlé, C. \& Quantin, G. 2009. The AMMACATCH experiment in the cultivated Sahelian area of south-west Niger - Investigating water cycle response to a fluctuating climate and changing environment. Journal of Hydrology, 375,34-51, DOI: 10.1016/j.jhydrol.2009.06.021

Elsebeer,H; Newton, B.E.; Dunne, T., and Moraes, J.M. 1999. Hydraulic conductivities of latosols under pasture, forest and teak in Rondonia, BRAZIL, Hydrological Processes 13: 1417-1422 DOI : 10.1002/(SICI)1099-1085(19990630)13:9<1417::AID-HYP816>3.0.CO;2-6

Elsenbeer, H. 2001. Hydrologic flowpaths in tropical rainforest soilscapes - a review. Hydrological Processes, 15: 1751-1759. DOI: http://dx.doi.org/10.1002/hyp.237.

Elsenbeer, H., Lack, A. 1996. Hydrometric and hydrochemical evidence for fast flowpaths at La Cuenca, Western Amazonia. Journal of Hydrology. 180: 237-250.

Feng, X., Faiia, A. M., and Posmentier, E. S. 2009. Seasonality of isotopes in precipitation: A global perspective, Journal of Geophysical Research., 114, D08116, DOI:10.1029/2008JD011279, 2009.

Gee, G. W. and Bauder, J. W. 1986. 'Particle size analysis', in Klute, A. (Ed.), Methods of Soil Analysis, Part I. Am. Soc. Agron., Madison, WI. 1188 pp.

Hamilton, L. S., J. O. Juvik and Scatena, F.N. 1995. The Puerto Rico Tropical Cloud Forest Symposium: Introduction and Workshop Synthesis. In: Hamilton, L. S., J. O. Juvik \& F. N. Scatena (eds.): Tropical Montane Cloud Forest. Springer, New York, 1-23.

Hodnett M.G, Oyama M.D, Tomasella J, Marques Filho O. 1995. Comparisons of long-term soil water storage behaviour under pasture and forest in three areas of Amazonia. In Amazonian Deforestation and Climate, Gash JHC, Nobre CA, Roberts JM, Victoria RL (eds). Wiley: Chichester; 57-77.

Ingram HAP. 1983. Hydrology. In Ecosystems of the World 4A, Mires: Swamps, Bog, Fen \& Moor, General Studies, Gore AJP (ed.). Elsevier Scientific Publishing Company: Amsterdam; $67-158$.

Kebede, S. and Travi, Y. 2011. Origin of the _18O and _2H composition of meteoric waters in Ethiopia, Quatern. Int., 257, DOI :10.1016/j.quaint.2011.09.032, . 
Lee, J. E., Johnson, K., and Fung, I. 2009. Precipitation over South America during the Last Glacial Maximum: An analysis of the "amount effect" with a water isotope-enabled general circulation model, Geophysical Research Letters.,36, L19701, DOI:10.1029/2009GL039265, 2009.

Lim, K. J., B. A. Engel, Z. Tang, J. Choi, K. Kim, S. Muthukrishnan, and Tripathy, D.2005. Automated Web GIS based Hydrograph Analysis Tool, WHAT. Journal of American Water Resources Association., 41: 1407-1416. DOI:10.1111/j.1752-1688.2005.tb03808.x

Lim, K. J., Y. S. Park, J. Kim, Y. Shin, N. W. Kim, S. J. Kim, J. Jeon, and Engel, B. 2010. Development of genetic algorithm-based optimization module in WHAT system for hydrograph analysis and model application. Computational Geosciences, 36: 936-944

Massuel, S., B.,Cappelaere, G.,Favreau, C., Leduc, T., Lebel and Vischel, T. 2011. Integrated surface-groundwater modelling in the context of increasing water reserves of a Sahelian aquifer, Hydrological Sciences Journal .56(7): 1242-1264. DOI:10.1080/02626667.2011.609171

Moraes, J.M., Schuler, A.E., Dunne, T., Figueiredo, R.O., Victoria, R.L. 2006. Water storage and runoff processes in plinthic soils under forest and pasture in Eastern Amazonia. Hydrological Processes 20: 2509-2526. Doi:

Niedzialek, J. M., and Ogden, F. L. 2010. First-order catchment mass balance during the wet season in the Panama Canal Watershed, Journal of Hydrology, 462-463: 77-86, DOI:10.1016/j.jhydrol.2010.07.044.

Pfeffer, J., Champollion, C; Favreau,G; Cappelaere,B; Hinderer, J; Boucher, M; Nazoumou, Y; Oï, M; Mouyen, M; Henri, C; Le Moigne, N; Deroussi, S; Demarty, J; Boulain, N; Benarrosh, B., and Robert, O. 2013. Evaluating surface and subsurface water storage variations at small time and space scales from relative gravity measurements in semi-arid Niger,. Water Resources Research. 49 (6): 3276-3291. DOI: 10.1002/wrcr.20235

Price J.S, and Maloney D.A. 1994. Hydrology of a patterned bog-fen complex in south-eastern Labrador, Canada. Nordic Hydrology 25: 313-330.

Recha, J. W., Lehmann, J., Walter,M.T., Pell, A, Verchot, L. and Johnson, M. 2012. Stream Discharge in Tropical Headwater Catchments as a Result of Forest Clearing and Soil Degradation. Earth Interactions., 16, 1-18. DOI: http://dx.doi.org/10.1175/2012EI000439.1

Roa-Garcia, M. C. and Weiler, M. 2010. Integrated response and transit time distributions of watersheds by combining hydrograph separation and long-term transit time modeling, Hydrology and Earth System Sciences, 14, 1537-1549, DOI:10.5194/hess-14-1537-2010. 
Roa-García, M. C., S. Brown, H. Schreier, and Lavkulich, L.M. 2011. The role of land use and soils in regulating water flow in small headwater catchments of the Andes, Water Resources Research 47 (5): DOI:10.1029/2010WR009582.

Scatena, F. N., Bruijnzeel, L. A., Bubb, P., and Das, S. 2010. Setting the stage, in: Tropical Montane Cloud Forests: Science for Conservation and Management, edited by: Bruijnzeel, L. A., Scatena, F. N., and Hamilton, L. S., Cambridge Univ. Press, UK, 3-13, 2010.

Schnorbus, M., and Alila, Y. 2013. Peak flow regime changes following forest harvesting in a snow-dominated basin: Effects of harvest area, elevation, and channel connectivity, Water Resour. Res., 49, DOI:10.1029/2012WR011901.

Schoenholtz, S.H., Van Miegroet, H., Burger, J.A. 2000. A review of chemical and physical properties as indicators of forest soil quality: challenges and opportunities. Forest Ecology Management 138 (1-3): 335-356.

Séguis, L., B., Cappelaere, G., Milési, C., Peugeot, S., Massuel, and Favreau, G. 2004. Simulated impacts of climate change and land-clearing on runoff from a small Sahelian catchment, Hydrological Processes, 18: 3401-3413. DOI: 10.1002/hyp.1503

Soil Survey Staff 1999, Soil Taxonomy A basic system of soil classification for making and interpreting soil surveys; 2nd edition. Agricultural Handbook 436; Natural Resources Conservation Service, USDA, Washington DC, USA, pp. 869

Suryatmojo, H, Masamitsu, F., Mizuyama, T. 2013.Effects of elective logging methods on runoff characteristics in paired small headwater catchment. Procedia Environmental Sciences 17: 221 $-229$.

Tognetti, S., Aylward, B., and Bruijnzeel, L. A. 2010. Assessment needs to support the development of arrangements for payments for ecosystem services from tropical montane cloud forests, in: Tropical Montane Cloud Forests. Science for Conservation and Management, edited by: Bruijnzeel, L. A., Scatena, F. N., and Hamilton, L. S., Cambridge Univ. Press, Cambridge, UK, 671-685.

Trancoso, R., Tomasella, J., Filho, A.C., Ferreira, M.T., Rodrigues, D.A., da Silva, R.C., Cuartas, L.A., Nascimento, A.H.M., Nascimento, T.A.M. 2007. Hydrological impacts of forest conversion to grassland in small catchments in Brazilian Amazon. In: 87th Conference on Hydrology, Texas, USA, 2007. http://www.lbaeco.org/lbaeco/meeting10/presentations/talks/2A-5.4.pdf.Accessed on July 31 2013 
Vogel, R. M., and Fennessey, N.M. 1994. Flow-duration curves I: New interpretation and confidence intervals. Journal of Water Resources Planning and Management, 120: 485-502

Williams MR, Fisher TR, Melack J.M. 1997. Solute dynamics water and groundwater in a central Amazon catchment undergoing deforestation. Biogeochemistry 38: 303-335.

Zadroga, F. 1981. The hydrological importance of a montane cloud forest area of Costa Rica, in: Tropical Agricultural Hydrology, edited by: Lal, R. and Russell, E. W., John Wiley and Sons, New York, NY, 59-73.

\section{FIGURE CAPTIONS}

Figure $1 \quad$ Study area location and study catchments instrumentation

Figure 2 Typical soil profiles in the two study catchments

Figure 3 Daily rainfall in the study catchments. (Average of the tipping buckets)

Figure $4 \quad$ Correlation between daily rainfall data from Forest and Pasture catchments

Figure 5 Time series of soil moisture (\% vol.) at three catena positions in the forest and pasture catchments.

Figure 6 Peak discharges and areal average rainfall in the study catchments

Figure $7 \quad$ Normalised discharges and areal average rainfall in the study catchments

Figure $8 \quad$ Flow duration curves for daily discharge data from the study catchments

Figure 9 Storm hydrographs for the rainstorm on March 232013 for the two study catchments

Figure 10 Example storm hydrographs from the two catchments.

Figure11 Daily Evapotranspiration and areal average rainfall for the study catchments 
Table 1 Soil horizon characteristics in the study catchments

Pasture: Clayic Lixisols

\begin{tabular}{|c|c|c|c|c|c|c|c|}
\hline $\begin{array}{l}\text { Horizon } \\
\text { Symbol }\end{array}$ & Depth $(\mathrm{cm})$ & Texture & Color & $\begin{array}{l}\text { Bulk Density } \\
(\mathrm{g} / \mathrm{cm} 3)\end{array}$ & Structure & Roots & Other features \\
\hline $\mathrm{A}$ & $0-5$ & Sandy Loam & 10YR 3/11 & 1.2 & $\begin{array}{l}\text { Block sub } \\
\text { angular moderate }\end{array}$ & $\begin{array}{l}\text { Few } \\
\text { Very fine }\end{array}$ & - \\
\hline E & $5-70$ & $\begin{array}{l}\text { Sandy clay } \\
\text { loam }\end{array}$ & $2.5 Y 6 / 4$ & 1.1 & $\begin{array}{l}\text { Block sub } \\
\text { angular moderate }\end{array}$ & $\begin{array}{l}\text { Very few } \\
\text { Very fine }\end{array}$ & \\
\hline $\mathrm{Bt}$ & $70-103$ & Clay loam & $2.5 Y 7 / 3$ & & $\begin{array}{l}\text { Block sub } \\
\text { angular moderate }\end{array}$ & none & \\
\hline & & & & 1.1 & & & - \\
\hline
\end{tabular}

Forest: Albic Lixisols

\begin{tabular}{|c|c|c|c|c|c|c|c|}
\hline $\begin{array}{l}\text { Horizon } \\
\text { Symbol }\end{array}$ & $\begin{array}{l}\text { Depth } \\
(\mathrm{cm})\end{array}$ & Texture & Color & $\begin{array}{l}\text { Bulk Density } \\
\left(\mathrm{g} / \mathrm{cm}^{3}\right)\end{array}$ & Structure & Roots & Other features \\
\hline A & $0-7$ & Sandy Loam & $\begin{array}{l}10 \mathrm{YR} \\
2 / 2\end{array}$ & 1.1 & $\begin{array}{l}\text { Block sub } \\
\text { angular } \\
\text { moderate }\end{array}$ & $\begin{array}{l}\text { Few } \\
\text { Very fine }\end{array}$ & - \\
\hline $\mathrm{E}$ & $7-47$ & Sandy clay loam & $\begin{array}{l}10 Y R \\
4 / 3\end{array}$ & 1.3 & $\begin{array}{l}\text { Block sub } \\
\text { angular } \\
\text { moderate }\end{array}$ & $\begin{array}{l}\text { Very few } \\
\text { Very fine }\end{array}$ & - \\
\hline $\mathrm{Bt}$ & $47-60$ & Clay loam & $2.5 Y 5 / 3$ & 1.4 & $\begin{array}{l}\text { Blocky sub } \\
\text { angular } \\
\text { moderate }\end{array}$ & None & - \\
\hline Bvm & $60-$ & Plinthic layer & - & - & - & - & Impenetrable \\
\hline
\end{tabular}


Table 2. Saturated Hydraulic conductivity $(\mathrm{cm} / \mathrm{hr})$ measured at two depths and three different positions in the study catchments

\begin{tabular}{cccc}
\hline Catenal Position & Measurement Depth & Pasture & Forest \\
\hline Upslope & $25 \mathrm{~cm}$ & 0.339 & 1.53 \\
& $40 \mathrm{~cm}$ & 1.66 & 0.915 \\
Middle Slope & $25 \mathrm{~cm}$ & 0.39 & 7.72 \\
& $40 \mathrm{~cm}$ & - & 4.34 \\
Valley Bottom & & & \\
& $25 \mathrm{~cm}$ & 0.77 & 6.01 \\
& $40 \mathrm{~cm}$ & 0.95 & 7.88 \\
\hline
\end{tabular}


Table 3: Hydrological analysis and indices for the study catchments derived from rainfall runoff data for the period January to May 2013

\begin{tabular}{|c|c|c|}
\hline Index & Pasture Catchment & Forest Catchment \\
\hline Discharge $(\mathrm{mm})$ & 992 & 584 \\
\hline $\mathrm{RC}^{\mathrm{a}}$ & 0.791 & 0.466 \\
\hline Storm Flow (mm) & 371 & 154 \\
\hline $\mathrm{RC}_{\mathrm{SF}}^{\mathrm{b}}$ & 0.296 & 0.123 \\
\hline Base Flow (mm) & 621 & 442 \\
\hline $\mathrm{RC}_{\mathrm{BF}}^{\mathrm{c}}$ & 0.495 & 0.352 \\
\hline $\mathrm{BFI}^{\mathrm{d}}$ & 0.626 & 0.757 \\
\hline Flashiness Index & 0.099 & 0.028 \\
\hline
\end{tabular}

$\mathrm{a}=$ total discharge/precipitation; $\mathrm{b}=$ storm flow/precipitation

$\mathrm{c}=$ base flow/precipitation; $\mathrm{d}=$ base flow/total discharge 
Table 4: Results from a mass balance exercise with summations of rainfall, runoff, ET, and residuals over the study period (Jan-May 2013) for the study catchments

\begin{tabular}{ccccc}
\hline Site & $\begin{array}{c}\text { Precipitation } \\
(\mathrm{P})(\mathrm{mm})\end{array}$ & $\begin{array}{c}\text { Discharge } \\
(\mathrm{Q})(\mathrm{mm})\end{array}$ & $\begin{array}{c}\text { Evapotranspiration } \\
\text { ET }(\mathrm{mm})\end{array}$ & $\begin{array}{c}\text { Recharge and change } \\
\text { in Storage }(\Delta \mathrm{S})(\mathrm{mm})\end{array}$ \\
\hline $\begin{array}{c}\text { Pasture } \\
\text { Catchment }\end{array}$ & 1254 & 992 & 445 & -183 \\
\hline $\begin{array}{c}\text { Forest } \\
\text { Catchment }\end{array}$ & 1190 & 584 & 560 & 46 \\
\hline
\end{tabular}




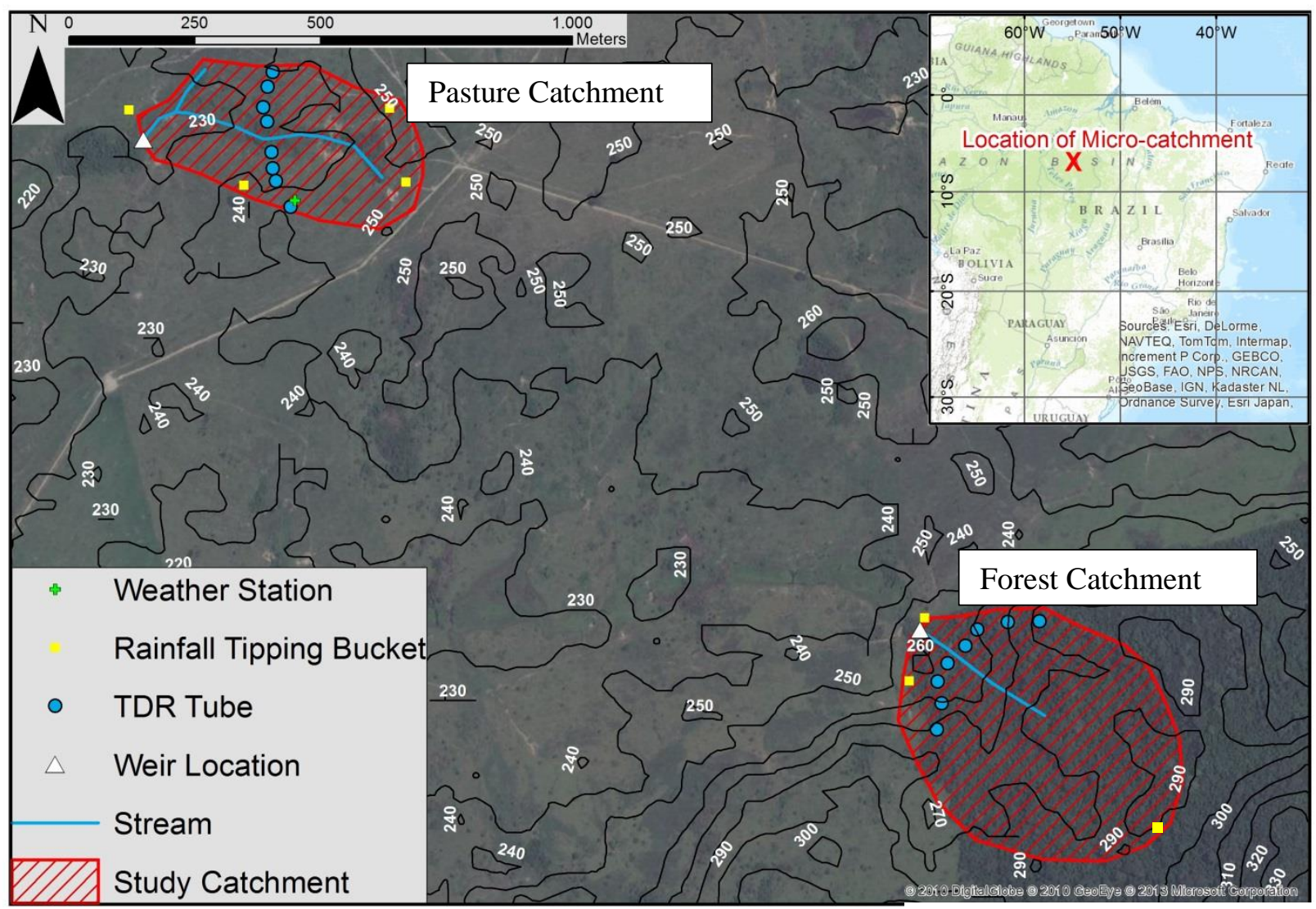

Drawn by: K. Kovacs

Figure 1 Study area location and study catchments instrumentation 


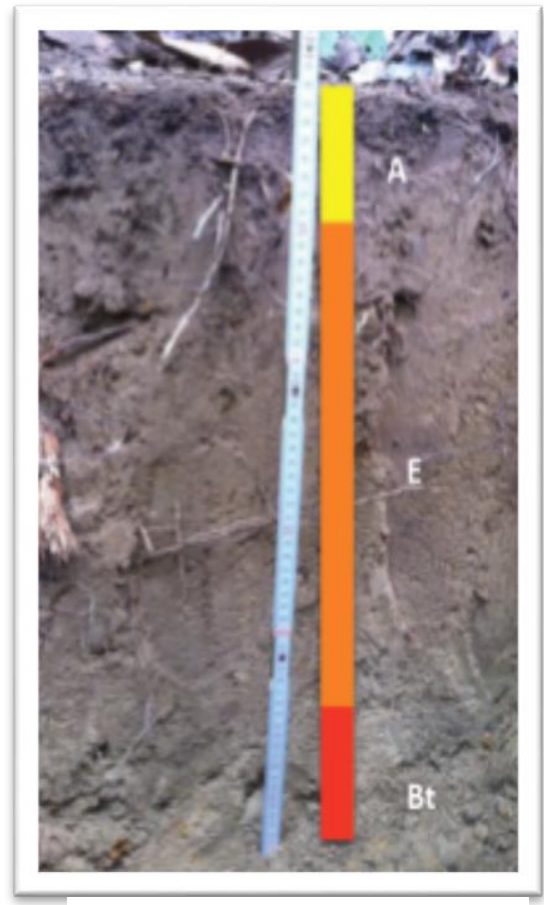

Forest: Albic Lixisol

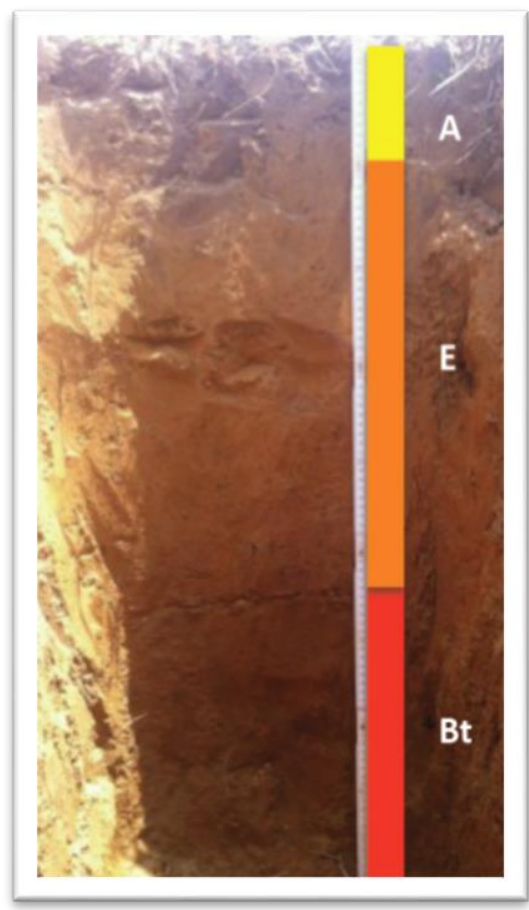

Pasture: Clayic Lixisol

(Photo: J. Rebola-Lichtenberg)

Figure 2 Typical soil profiles in the two study catchments 


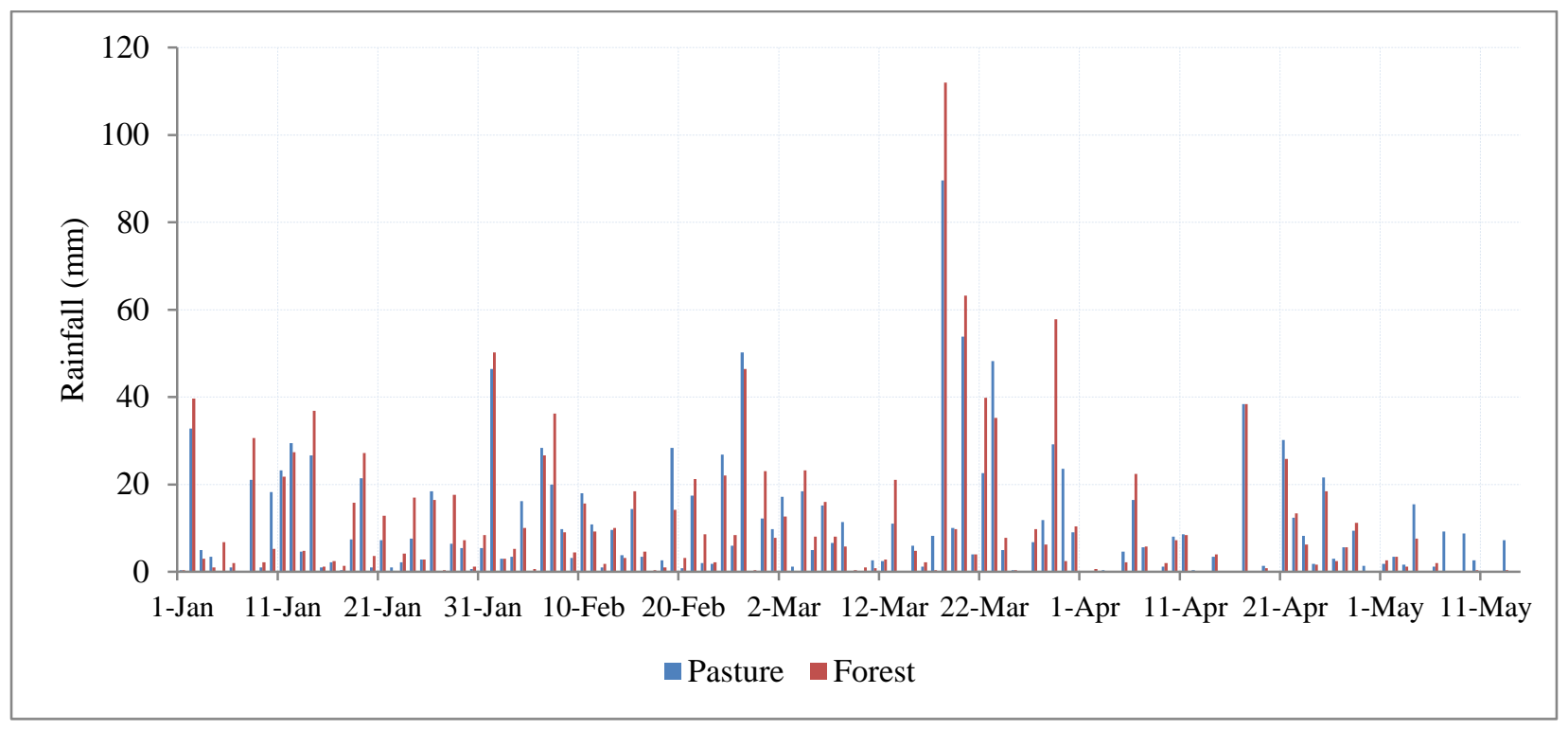

Figure 3 Daily rainfall in the two study catchments. (Average of the tipping buckets) 


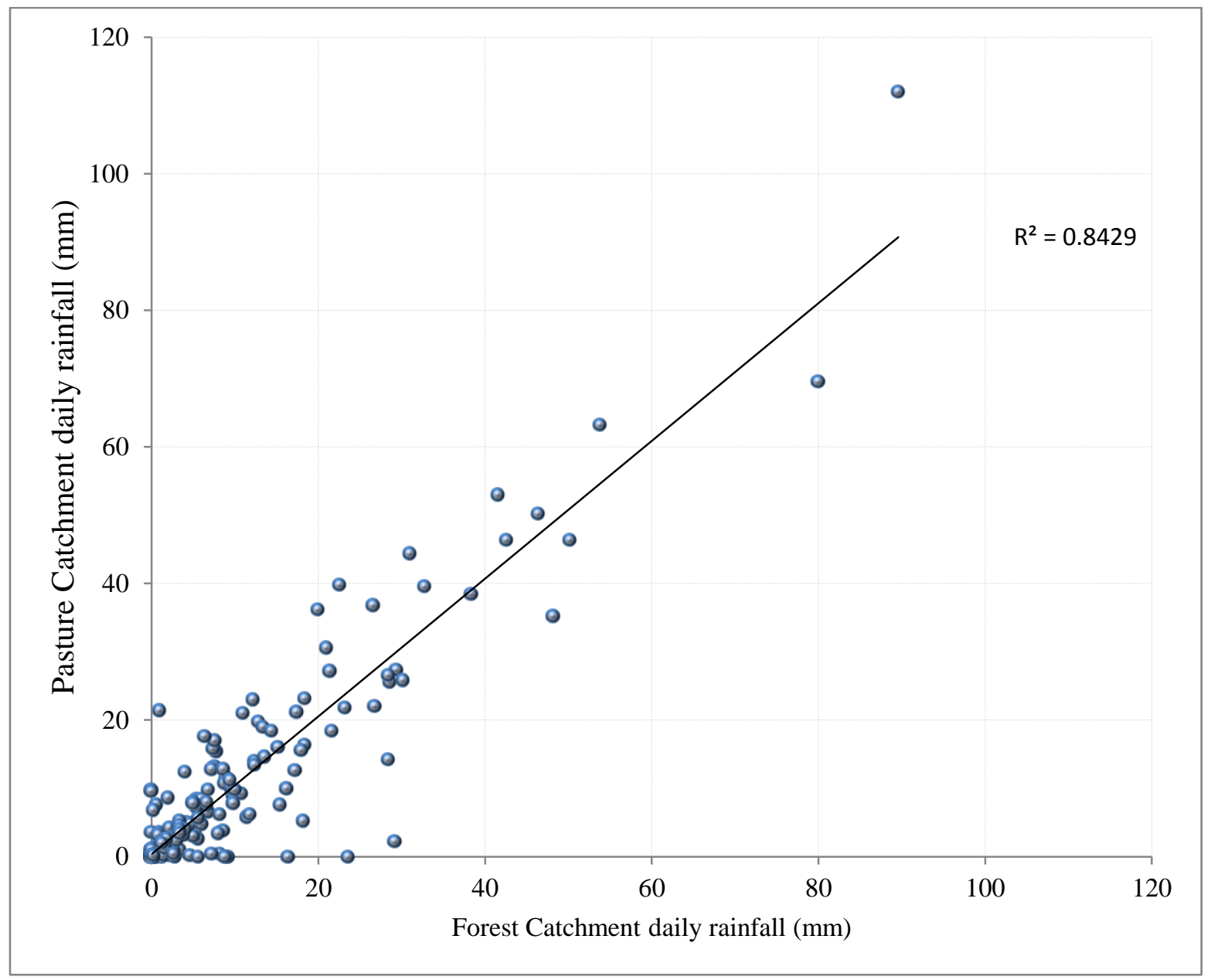

Figure 4 Correlation between daily rainfall data from Forest and Pasture catchments 

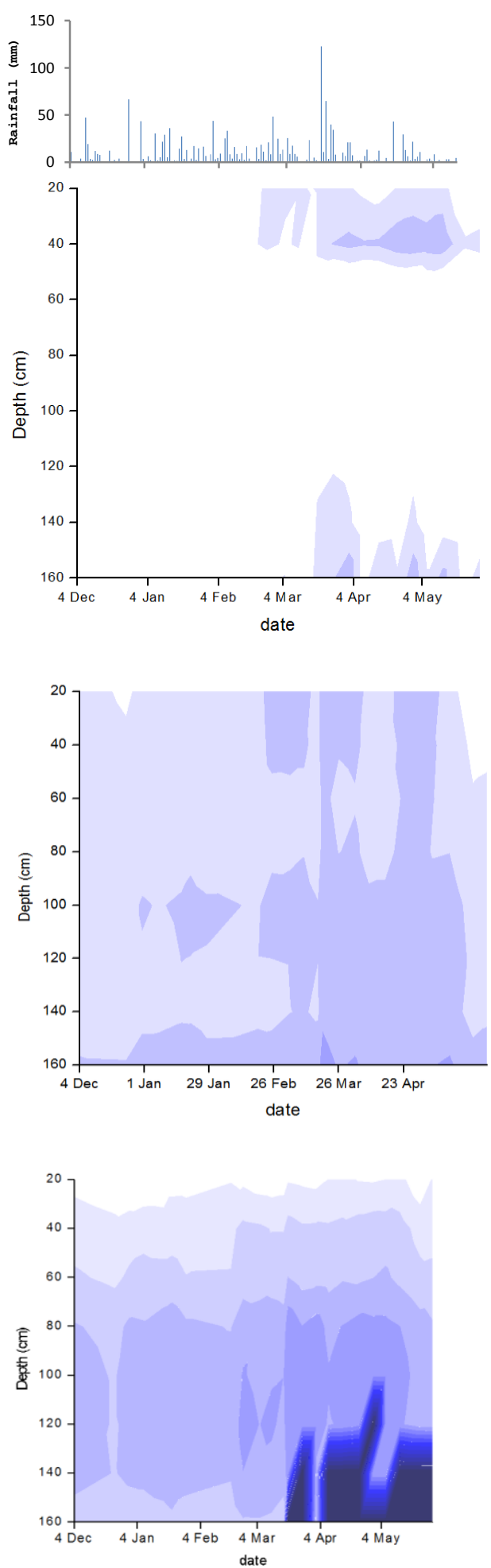
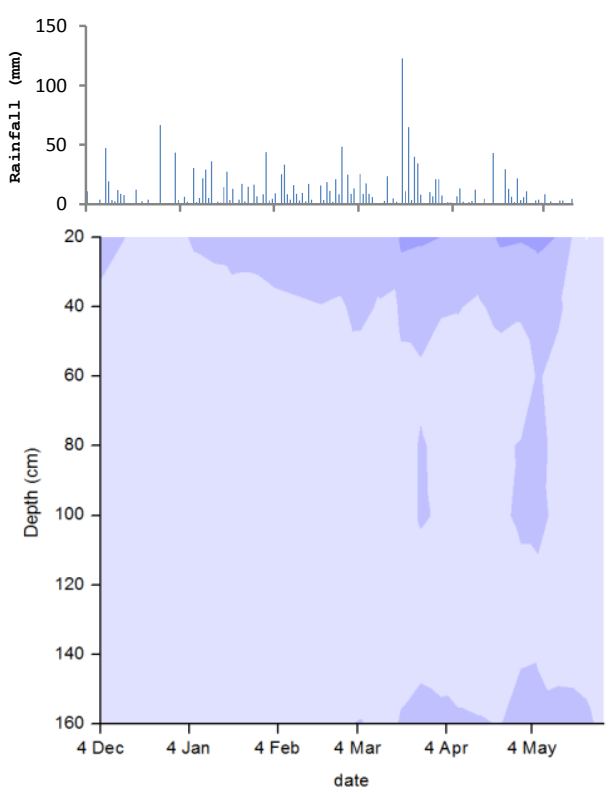

Upslope

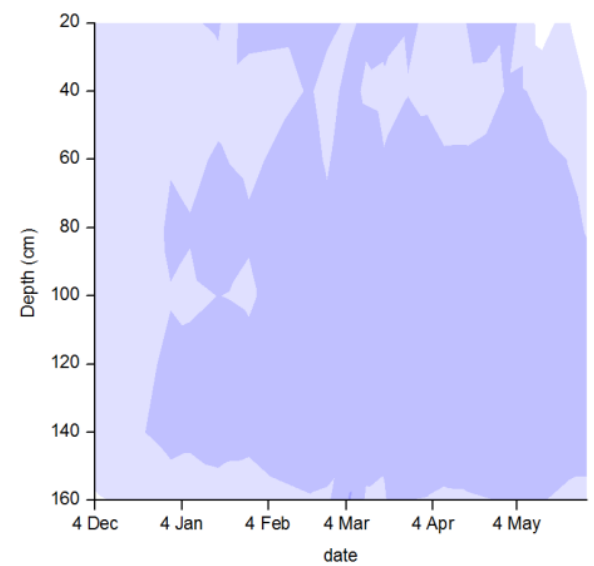

Middle

Slope

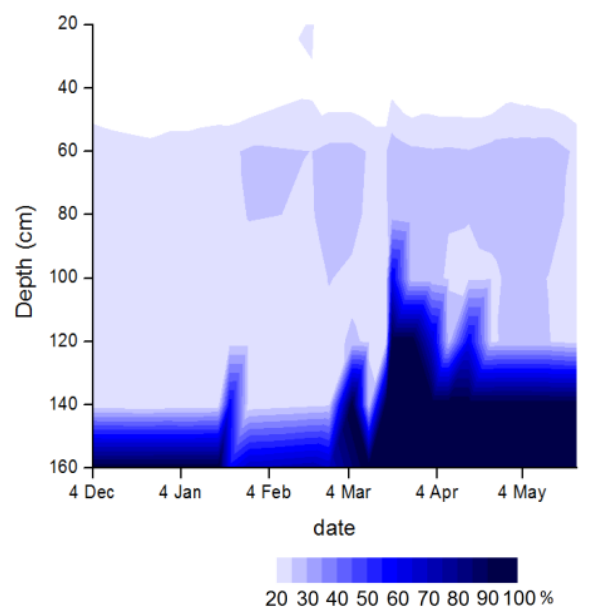

Valley

bottom

Figure 5 Time series of soil moisture (\% vol.) at three catena positions in the forest and pasture catchments. 


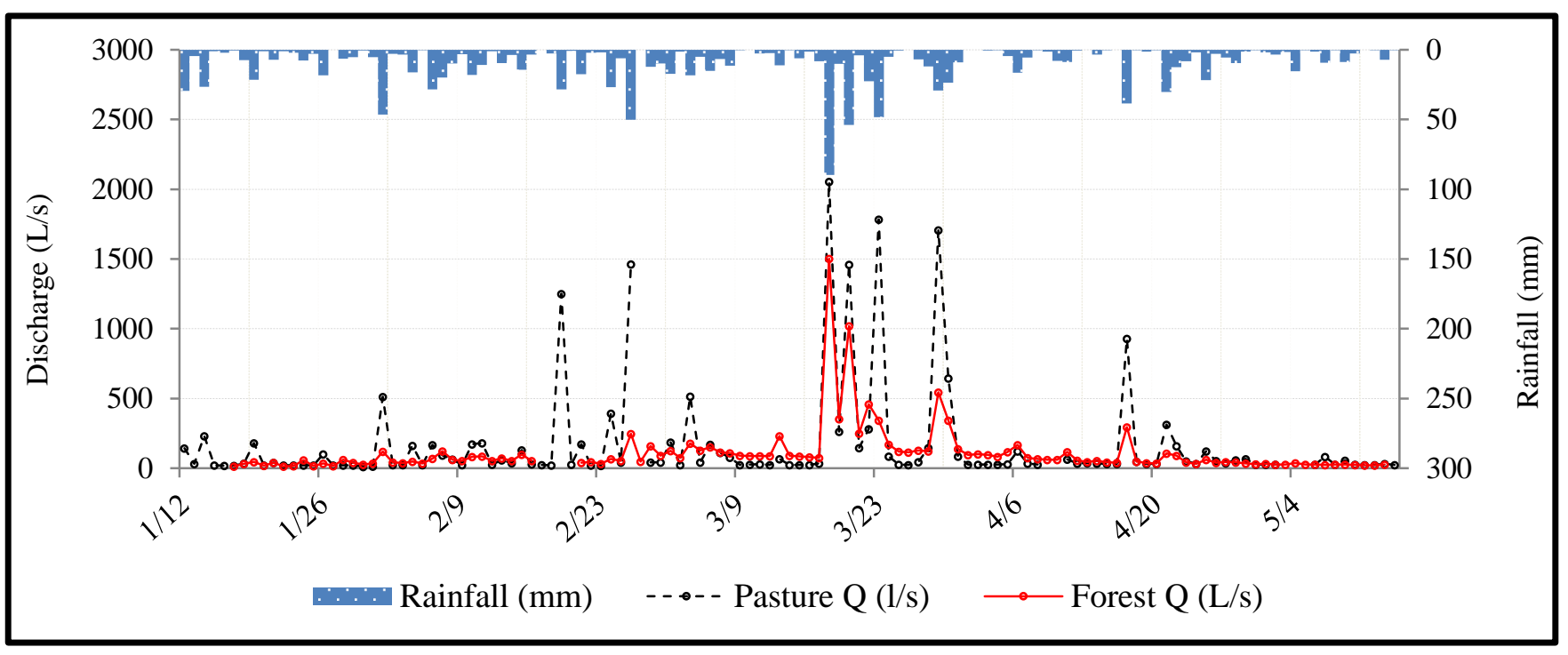

Figure 6 Peak discharges and areal average rainfall in the study catchments 


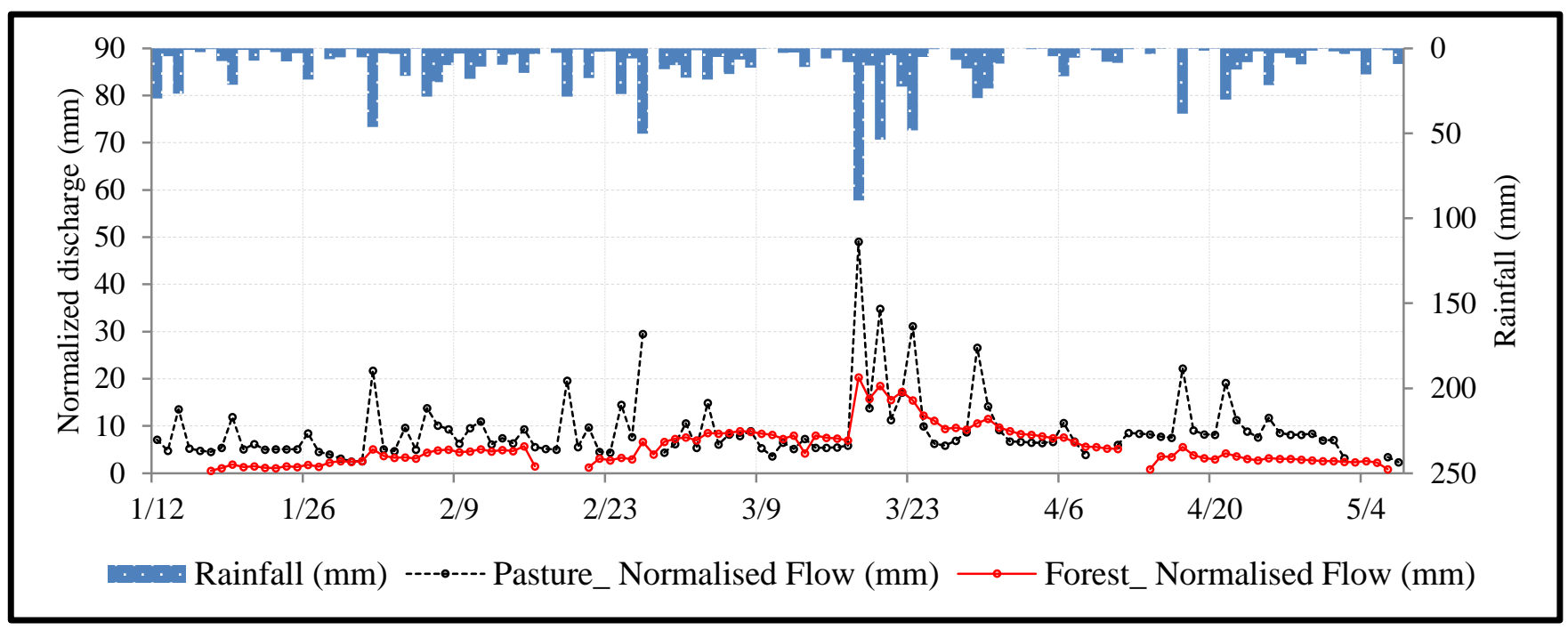

Figure 7 Normalised discharges and areal average rainfall in the study catchments 


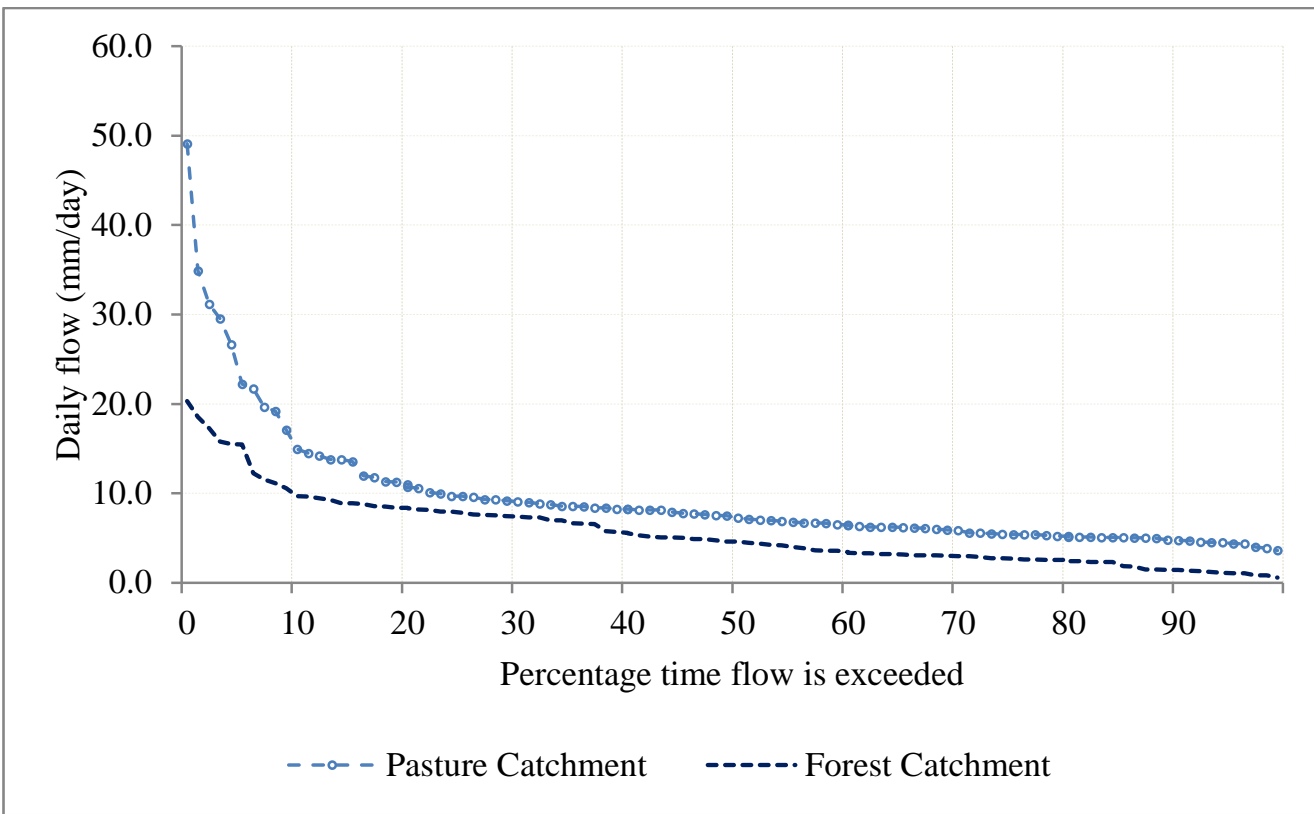

Figure 8 Flow duration curves for daily discharge data from the study catchments 


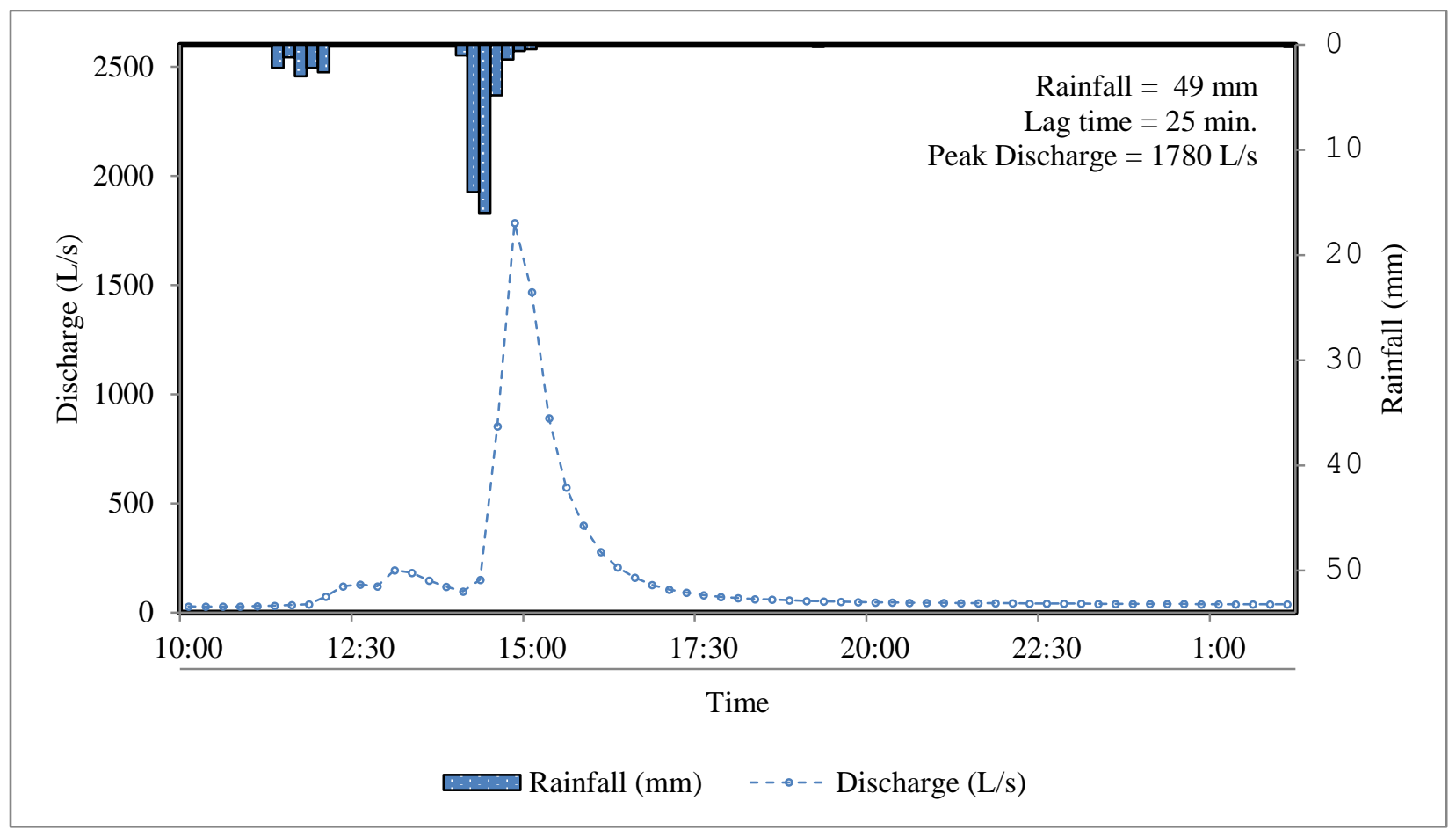

(a) Pasture catchment

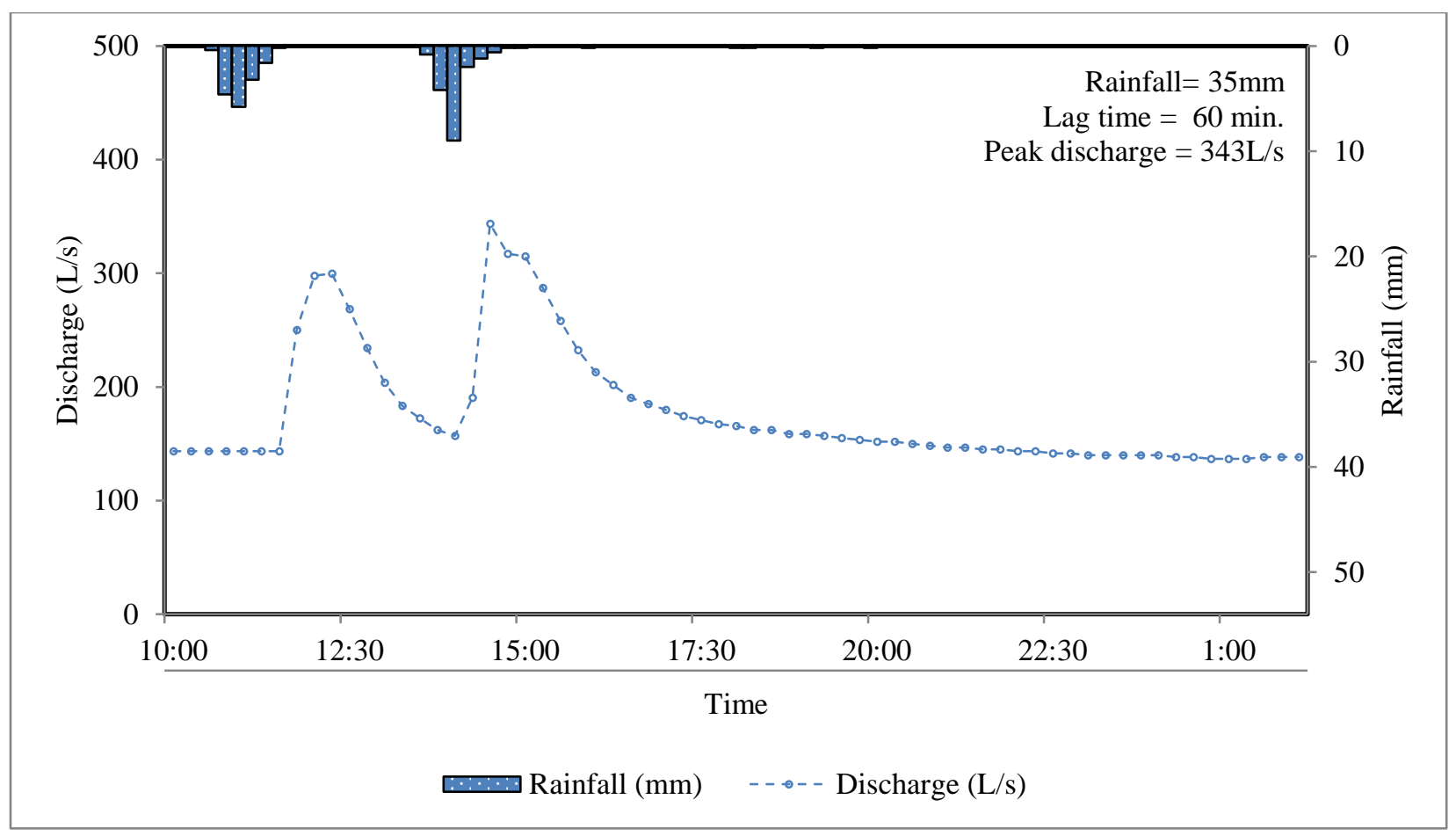

(b) Forest Catchment

Figure 9 Storm hydrographs for the rainstorm on March 232013 for the two study catchments 
February 262013

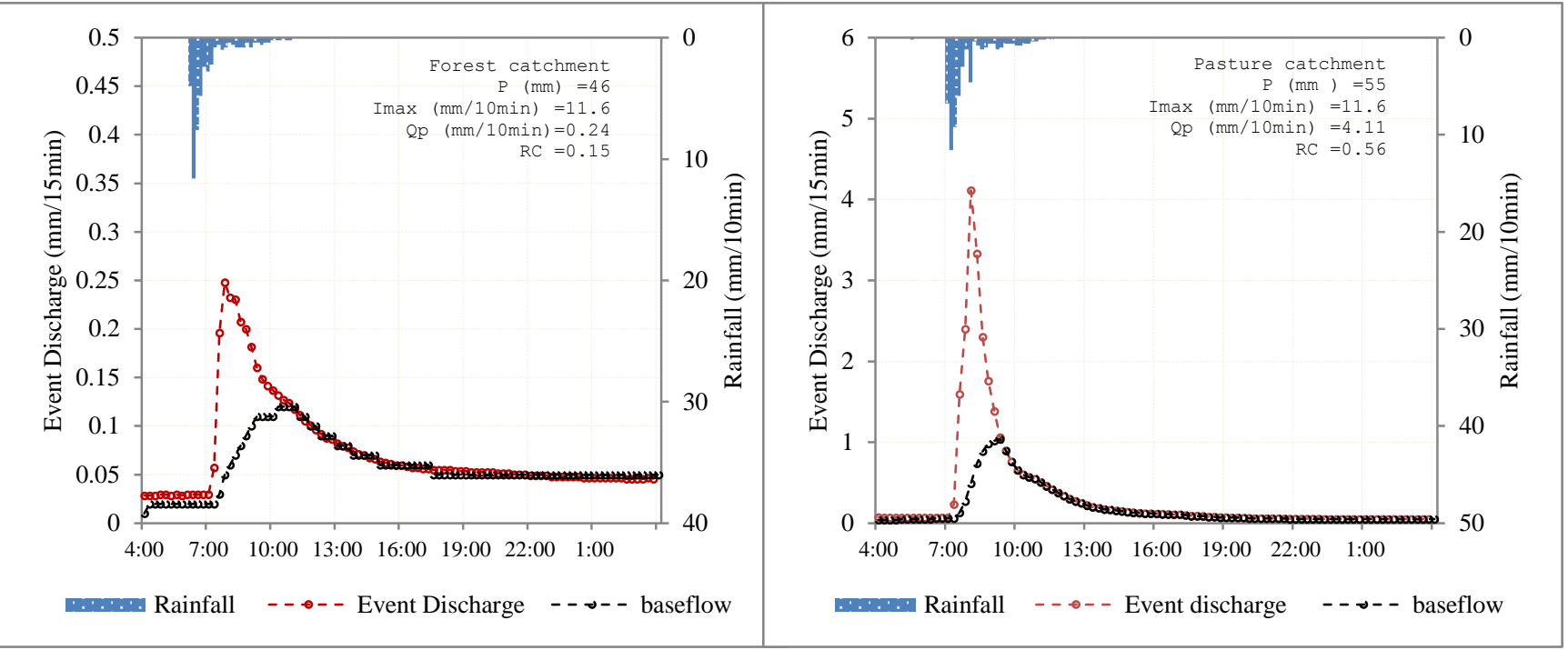

March 182013

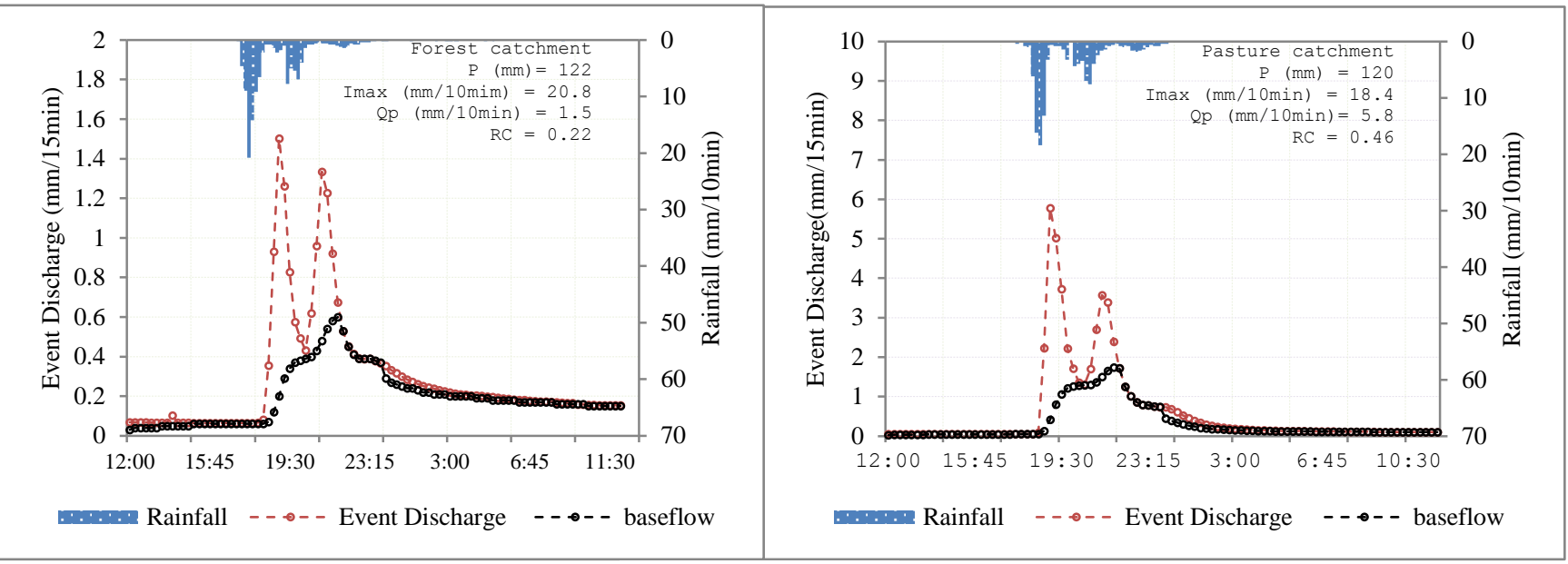

April 172013

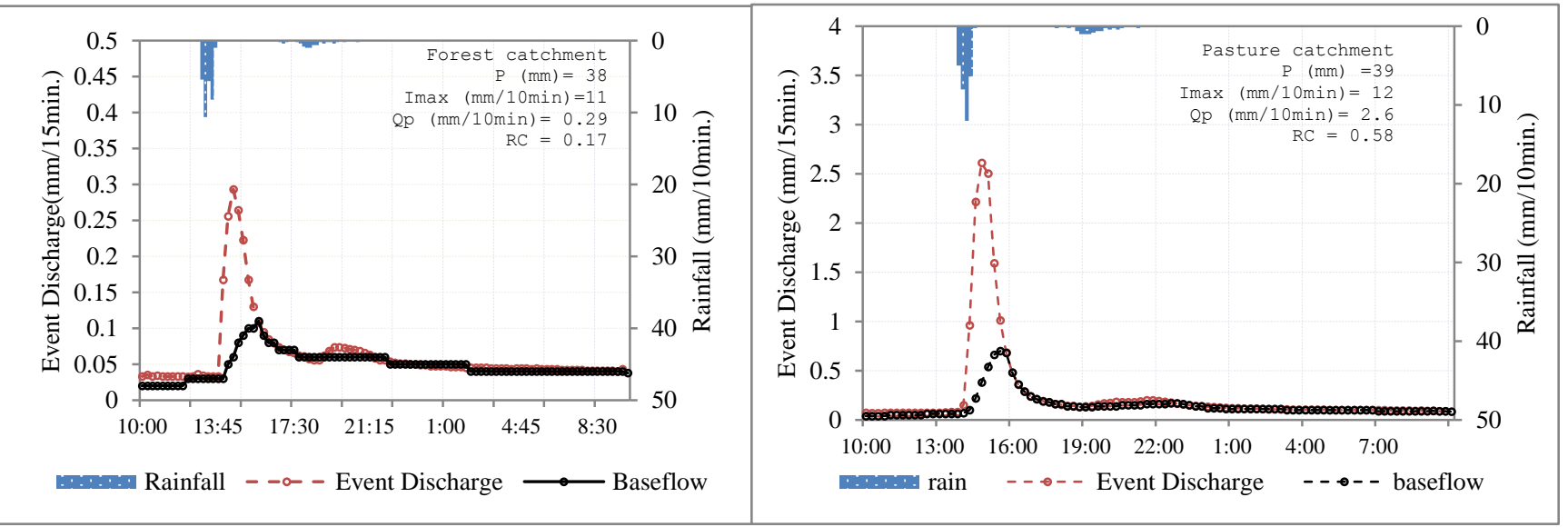

Figure 10 Example storm hydrographs from the two catchments. Precipitation (P, mm), maximum intensity of precipitation $(\mathrm{mm} / 10 \mathrm{~min})$, Peak discharge $(\mathrm{Qp}, \mathrm{mm} / 10 \mathrm{~min})$, and runoff coefficient (RC). 


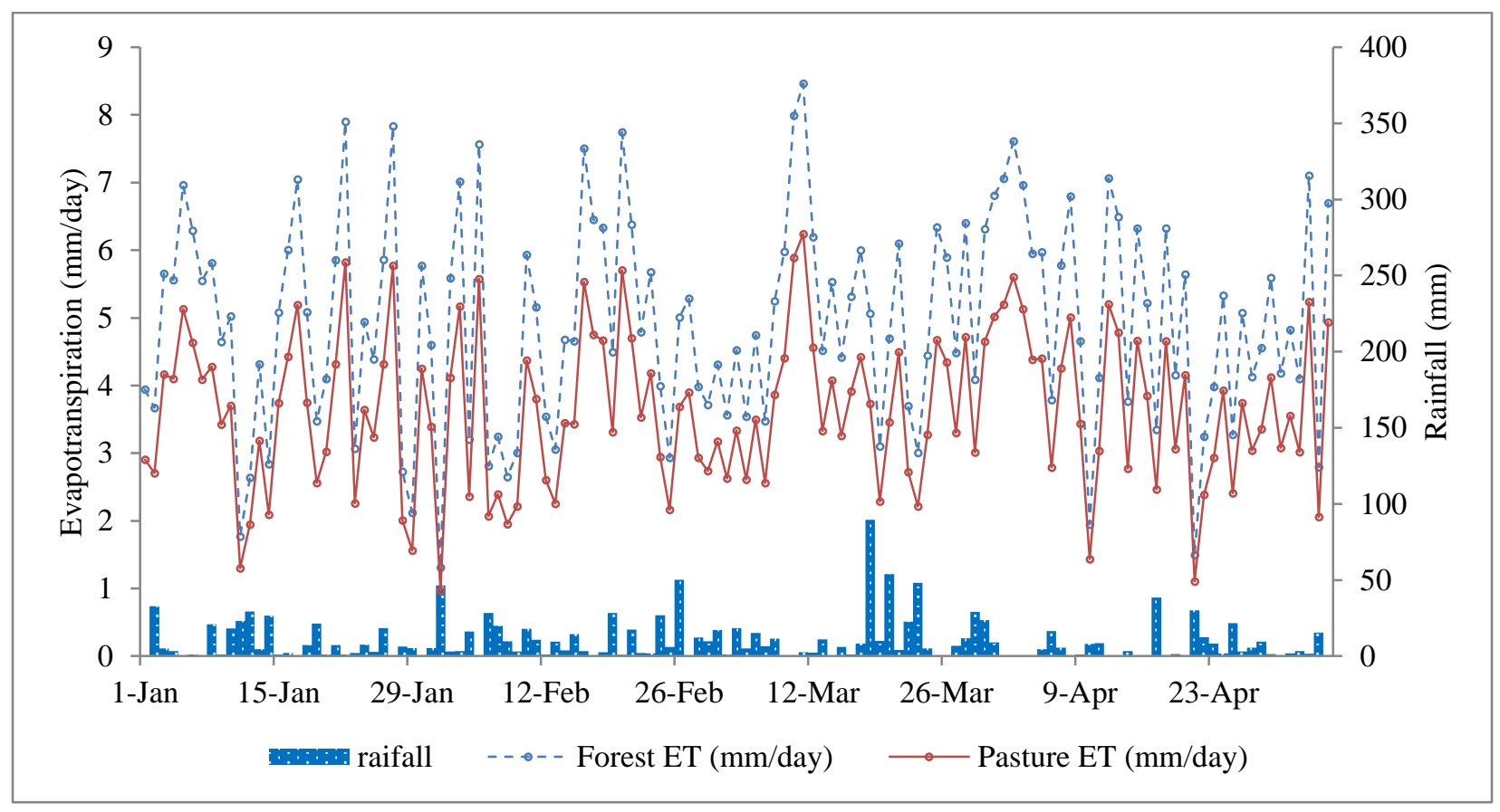

Figure 11 Daily Evapotranspiration and areal average rainfall for the study catchments 